\title{
Effect of Labour Market Changes on HR Functions
}

\author{
Ефекти промене тржишта радне снаге на функцију \\ људских ресурса \\ Mária Héder *
}

University of Debrecen, Károly Ihrig Doctoral School of Management and Business, Debrecen, Hungary

Szilvia Szabó**

National University of Public Service, Faculty of Science of Public Governance and Administration, Budapest, Hungary

\author{
Krisztina Dajnoki** \\ University of Debrecen, Faculty of Economics and Business, Debrecen, Hungary
}

\begin{abstract}
Simultaneously with social, economic transformation, management of the human factor in the world of labour has become increasingly important. People as resources are essential for the effective management of every company; the changing environment requires rational management of resources. The impact of changes within the labour market observed in our time is the strongest on the field of human resource management. The importance of effective workforce management has increased considerably, which raised the significance of human resource professionals and their activities and demanded a certain change in attitude. The impact of globalisation and the lack of workforce and talent also affected the development of HR functions. Besides socalled conventional functions appearing in every organisation irrespective of its organisational size and activity, new areas of activity have been constantly emerging over the past decades, responding to changes in macroand micro-environment. In our present study, we highlight the characteristics and significance of HR branding, retention, knowledge, competence, talent and flow management from amongst the new trends.
\end{abstract}

Keywords: branding, retention, talent, flow, competency, knowledge

Сажетак: Напоредо с друштвеним и економским трансформацијама, управљање људским фактором у свету радне снаге све више добија на значају. Људи као ресурс неопходни су за ефикасно управљање сваком компанијом. Окружење, које је у сталном процесу промене, захтева рационално управљање ресурсима. Утицај промена које су у данашње време приметне на тржишту радне снаге најјачи је у области управљања људским ресурсима. Значај ефикасног управљања радном снагом је у великој мери порастао, што је нагласило важност стручњака из области људских ресурса и њихових активности и захтева извесне промене у ставовима. Утицај глобализације и недостатка радне снаге и талента одразио се и на развој функције људских ресурса. Поред такозваних конвенционалних функција, које се појављују у свакој организацији без обзира на њену величину и делатност, последњих деценија се непрестано појављују нова поља активности, која реагују на промене у макро и микро окружењу. У овом истраживању наглашавамо карактеристике и значај брендирања и задржавања људских ресурса, компетенција, управљања знањем, талентом и токовима, међу осталим новим трендовима.

Кључне речи: брендирање, задржавање, таленат, ток, компетенција, знање.

\footnotetext{
*₫heder.maria@econ.unideb.hu

***szabo.szilvia@uni-nke.hu

${ }^{* * * *} \bowtie$ dajnoki.krisztina@econ.unideb.hu
} 


\section{Development of human resource management functions}

There are two distinct tasks within the area of human resource management. One of these tasks is the fulfilment of organisational objectives, for which adequate human capital needs to be assured and the conditions for the operation and efficient use of human resources must be established. The other task is to meet the needs and expectations of individuals operating the organisation, and to develop the motivation and satisfaction of employees. Namely, to create an atmosphere in the workplace that will ensure that employees are able to use their skills and knowledge as effectively as possible for the sake of the organisation.

The essence of human resource management can be summarized in the following principles (Berde - Dajnoki, 2007):

- Human resources are the most important asset of all organisations; their effective management is the key pillar of successful operation.

- Business success can be achieved through human resources if the personnel policies and principles of companies are closely linked to the mission and strategic goals of the organisation.

- Organisational culture, corporate values, atmosphere and managerial behaviour culture greatly influence employees towards achieving better performance. Therefore, it is the responsibility of the management to strengthen or change the scale of corporate values, or to have it accepted by the employees so that that the entire organisation functions in the spirit of these values.

Human resource management is a functional area without which the operation of organisations is not imaginable anymore. Looking back on the history of human resource management activities, significant changes can be observed. Instead of the administrative, operative role (Personnel Administration), currently we talk about strategic human resource management, where the role of $\mathrm{HR}$ appears in the development of competitiveness, and business/strategic partnerships with other organisational managers. The role of HR activities is intensifying, professionalization is observed and integrated operation is realised (HR functions exist in harmony with each other).

Currently, strategic human resource management includes numerous areas of activity that can be divided into further sub-processes. Traditional functions (planning of employee numbers, job design, recruitment, selection, motivation, performance appraisal and development) have been expanded, and in response to ongoing environmental changes and challenges, new features have emerged which are or can be integrated into the HR strategy (Figure 1). 
Figure 1. HR functions

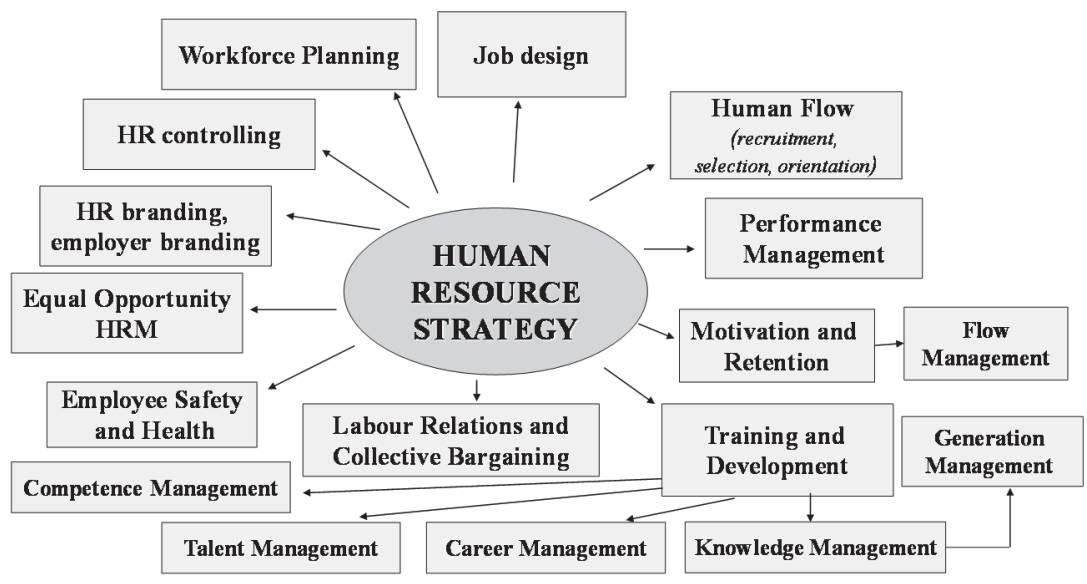

Source: Completed on the basis of Dajnoki (2014)

HR brand building has become part of the business strategy in the practice of more and more large companies. On some portals, they are referred to as independent professions as "HR/employer brander" who are responsible for the internal and external marketing of HR, which is realised through HR functions that are present in the organisational practice. In the process of labour supply, besides the tasks of recruitment and selection, the importance of integration has also increased. With a conscious integration programme, the actual competence of the employee will be sooner revealed, which will help gain his/her sense of comfort and security faster, which results in sooner satisfaction and increased performance. The approach of an integrated system is reinforced by the fact that instead of performance evaluation and motivation, performance management and motivation management, which are related to retention and training development, can be found in practice. Career management, which is currently interpreted as an independent function, can be linked to the latter function as well as knowledge and competence management.

As a result of increased expectations, competition, stress, psycho-terror and mobbing phenomena, we can currently address health preservation instead of work safety. According to our interpretation, equal opportunity-based human resource management focuses primarily on the exploration of the HR characteristics of employees with reduced capacity to work or employees with disabilities, which of course does not mean that the approach of equal opportunity should be applied to all HR functions.

Although not necessarily considered an HR function, HR controlling and "measurability" are still important to mention since the indexes used for analysis provide information for managerial decisions. 
The youngest HR functions are closely related to existing areas of activity and environmental changes. In the background of diversification management, there is globalisation triggered workforce migration, because of which managers realised that diversified employees might result in a diverse range of competences. However, diversity management can also be linked to generations. Generational management usually addresses the development, motivation and satisfaction of intergenerational cooperation, which might result in the change of organisational culture, introduction of new types of job design methods, emergence of knowledge transfer managementrelated tasks of older employees and the avoidance of age discrimination. In the following section, the features of HR branding, retention, knowledge, competence, talent and flow management are highlighted.

\section{Significance of HR branding within the organisation}

Employer brand and image are in close connection mainly with human resource management and marketing (Wojtaszczyk, 2012), as well as strategic management, strategic human resource management, competitive market strategy and successful management (Minchington, 2013).

Ambler and Barrow (1996) defined HR brand as "the package of functional, economic, and psychological benefits provided by employment, and identified with the employing company." According to Kim (2012) "managing the HR brand thus entails managing the aspects of a company's reputation and image, communicated to both current and prospective employees ". One of the aims of creating an attractive employer brand is to attract the most talented workers. If the external communication of the organisation suggests, "come and work for us, because we respect you, pay attention to your satisfaction, development and appreciate your talent ...", then it is probably the best-qualified employees will apply to us, which can be a competitive advantage compared to other organisations. With regard to the internal communication of the brand, our objective is to keep existing employees, namely to ensure them through organisational communication, that they can turn to HR professionals anytime in order for them to become satisfied employees within the organisation who provide the expected performance, and who are motivated and loyal. Based on the above, it is essential to apply conscious and organised development of the employer brand, which can be considered as a strategic tool for companies.

Every company may apply a different approach to measure the efficiency of its employer brand; there is no uniform method. According to Hegedüs - Nagy (2014), the following factors are taken into account by companies in the case of return: employee loyalty (44\%), fluctuation (41\%), number of applicants $(34 \%)$, quality of employee recruitment $(33 \%)$, costs of selection per hired employee $(33 \%)$.

According to the results of the research conducted by Hewitt, strengthening of the employer brand has multiple effects that are beneficial for the organisation, 
including increased corporate attractiveness, strengthened retention ability of the organisation, and established employee engagement (Mosley, 2009). Thus, the clear consequence of the above is that a more dominant employer brand can be associated with higher-than-average employee participation and ultimately contributes to achieving favourable financial results.

The employer brand is constituted by numerous elements, such as the attractiveness of the sector, reputation of the company, product quality, service, location, work environment, wage, economic conditions, employee benefits, employees and organisational culture, balance of work and private life and corporate responsibility (Figurska and Matuska, 2013). Within an organisation, these factors establish the internal engagement of employees, strengthen their loyalty and contribute to a situation where employees do their job within the organisation not only because of subsistencerelated reasons, but they develop an attachment and are happy to work and ultimately consider their job an experience. Examining the importance of factors affecting the employer brand, Kovács (2017) found that the most important factors are personality of managers, safe working conditions, attractive wages, development and career opportunities, personality of colleagues, proper working environment and teamwork.

\section{It is not enough to find them; they must be retained}

Besides acquiring employees with abilities and skills required by the organisation, it is of the utmost importance - due to the lack of employees - to retain talented, trained and proven employees. As a result of our aging society, the number of potential employees is decreasing; this reduction is also intensified by the migration of able workforce. Consequently, according to Canton (2013), the value of workforce is raised, on the other hand, the organisation has to deal with a larger amount of tasks than before, with a lower number of employees - taking into consideration the constantly increasing number of consumers - but in return, employees also have higher expectations towards their employers.

The importance of retention management is also supported by the research of 'HR portal' (2017, 2018), which annually examines the key tasks of HR in Hungarian organisations. Compared to 2017, there is no change in terms of the most important tasks; employee retention and in this context increasing employee loyalty are the most important goals according to the responding HR managers. 
Table 1: Key tasks of HR in 2017 and 2018

\begin{tabular}{|l|l|l||}
\hline & \multicolumn{1}{|c|}{2017.} & \multicolumn{1}{|c|}{2018.} \\
\hline \hline 1. & Employee retention & Employee retention \\
\hline 2. & Increasing employee engagement & Increasing employee engagement \\
\hline 3. & Strengthening the strategic role of HR & Recruitment \\
\hline 4. & Recruitment & Development of managers \\
\hline 5. & $\begin{array}{l}\text { Improving the attractiveness of the } \\
\text { employer brand - HR Branding }\end{array}$ & Strengthening the strategic role of HR \\
\hline 6. & Development of managers & $\begin{array}{l}\text { Improving the attractiveness of the } \\
\text { employer brand - HR Branding }\end{array}$ \\
\hline
\end{tabular}

Source: Own editing on the basis of hrportal $(2017,2018)$

Examining the retention and fluctuation management practices of Hungarian organisations, Poór et al. (2012) revealed what sort of personnel programmes are applied by the participating companies in order to improve retention and long-term motivation of their employees. It was found that the 17 different programmes listed by them are mainly used by foreign companies and international joint ventures. Benefits, foreign missions, key personnel programme, award-based service recognition programme, special training programme, and individual development plan are more common in the case of foreign companies and international (domestic-foreign) joint ventures than domestic ones. Higher than the market average wages, company car allowance, career management programme, and cash-based service recognition programme are mostly characteristic to foreign companies while loyalty programmes which combine multiple elements are preferred by mixed international companies.

The ability of organisations to retain their employees is influenced by the management attitude, consequently also by the role of HR, its significance within the organisation and the quality of elaborated HR systems. Based on the research results of Csedó et al (2016) acquired in the scope of Hungarian organisations $(n=328)$, the most commonly used employee retention tools in practice are performance management and the financial bonus system, while in the case of attracting and retaining talented employees, special training programmes and the individual development plan are of paramount importance. However, if the organisation provides a framework for feedback and implementation of innovative ideas, it also has a positive impact on the loyalty of talented employees

According to Allen (2008), certain HR practices can be especially powerful in enabling an organisation to achieve its retention goals. These practices include human flow (recruitment, selection and socialization), training and development, compensation and rewards, supervision, and employee engagement.

Employee satisfaction affects the degree of loyalty, namely retention rate. According to Select International's consultant, Thomas (2017), companies should consider the following aspects if they intend to retain their talented employees. In 
addition to the creation of appropriate work environment and job security (1), clearly defined goals and expectations are important, in which organisational communication and job descriptions are of key importance (2). It is required to recognise, appreciate and reward good work (3), as well as to maintain an open work environment with regular feedback (4). Last but not least, the promotion of training and development as well as challenging and motivating work tasks are also significant.

\section{Competence and knowledge management, as less and less negligible $H R$ functions}

At a practical level, the key role of competence appeared in multinational organisations involved in market competition in the context of human resources, but finally it has also become a part of the life of small organisations. Competence-based thinking has resulted in a paradigm shift in business life; in consequence, performance and efficiency during work are determined by skills, abilities and expertise, namely competence and suitability instead of acquired school certificates and degrees (Szabó, 2012). Instead of static systems, flexible frameworks are needed to support organisations in the new business environment. Therefore, competence management became a very common term within the HR profession; however, it is important to define the basic concept before it is interpreted. Act CI of 2001 on Adult Education explains competency as a set of knowledge, abilities, skills, attitudes and behavioural characteristics of the individual in practice, which enables him/her to perform certain tasks. According to the DeSeCo (Defining and Selecting Key Competencies 19972002) programme, competence is an ability to complete complex tasks in a given context successfully. The complexity of the concept is perfectly clear from the definitions. Competence jointly refers to mobilisation of knowledge, social and behavioural components and attitudes, cognitive and practical abilities, emotions, values, self-image and social roles that can be acquired during the life of a person (Parry, 1996; McLagan, 1998) and that - in terms of HR - can be utilised during work.

Competence management promotes the organisational level application of individual competences; it primarily provides a basis for the realisation of organisational objectives by allowing - as a coherent series of activities - the design and assurance of necessary resources and the optimal use and development of available competence potential by which employee performance is able to steadily increase (Henczi and Zöllei, 2007). Competence management at organisational level is therefore intended to serve the competence-based organisation of certain human functions, which will fundamentally determine the nature of the entire organisational human strategy (Szabó, 2016).

HR manages its functions in an integrated manner, which results in everything being interconnected; therefore, it can be said that competence management gains its meaning within the close relationship of most HR functions. There are opinions (Laakso-Manninen and Viitala, 2007) that knowledge and competence management are 
concepts that are so similar that they can be substitutes for each other at organisational level. The reason for this is that the definition of knowledge management has two main dimensions: on the one hand, the system reliable for the efficient management of knowledge, and on the other hand, the framework of processes related to the growth and dissemination of knowledge. In terms of the second dimension, knowledge management is closely linked to personal learning, encouraging people to develop both individually and as part of a team and share their knowledge with others. Individual development also affects the knowledge, abilities, skills and competences of the people involved, by which they can increase their workplace performance.

The most important goal of knowledge management is to enhance corporate productivity through the productive use of knowledge, which is realised through IT (information management systems, artificial intelligence, groupware systems) and human resources (human management, acquisition, modification and development of the abilities of individuals) by companies (Veresné, 2013). Bencsik and Juhász (2018) points out that the analysed knowledge-oriented companies typically handle the importance of knowledge at a strategic level, and consciously employ several kinds of solutions to manage it. Organisations are typically open to the development and preservation of any form of knowledge that demonstrates the growing dominance of the area as well.

Due to environmental changes, companies have a growing need for complex problem solving, critical thinking, creativity, people management, coordinating with others, emotional intelligence, judgment and decision-making (Gray, 2016). These cannot be linked to a particular qualification or skill level; they rather depend on the scope of individual competences. Therefore, it is important for the individual competence of employees to be consciously measured, screened, applied and developed by companies, since aggregated individual knowledge and experience will result in corporate knowledge, which also determines competitiveness. Competencebased organisation of work and the proper level of knowledge management can therefore fundamentally change organisational behaviour, but it requires an open professional approach, a developing environment and active managerial support, as well as the integration of existing best practices into the organisation.

\section{Conscious use of talent for the benefit of individuals and the company}

In business, it is often stated that the highest value of an organisation is provided by the employees working there. The essence of talent management is to raise awareness of this idea in corporate operations and to organise work processes accordingly. To manage talent at an appropriate level, it is important to understand that this is one of the opportunities for the organisation to emerge from amongst its competitors; namely, for enhancing competitiveness, internal resources of the organisation have to be supported. In order for our competitiveness to be sustainable, we must make our talent 
sources unique, since if something becomes easy to reproduce, it is less valuable and does not represent competitive advantage in the end. This means that an organisation is only as strong or weak as the individuals that form it - more precisely the combination of knowledge, skills, motivation and talent of the constituting individuals will determine the corporate balance of power. Corporate talent management is one of the fundamental sources of sustainable competitiveness where the focus is on acquiring exceptional human talents (Ferry, 2014). Results of a survey conducted amongst Hungarian university students show that the most important components of talent are fluent speaking, the ability of essentiality, problem recognition, original thinking, endurance and internal motivation according to the respondents, which can be fully paralleled with Renzulli's talent model and theory (Gergely et al., 2017). However, considering that the frequent lack of talent and job skills is becoming a typical phenomenon (beyond general lack of workforce) in the labour market, this scarcity can be overcome by the operation of talent management systems on the organisational side. Consequently, involving available talents, the objective is to develop models that utilise available talent sources in an innovative way by employing the most recent technology. As a result of the above, talent management is not only the responsibility of HR but also a major tool for business management, which is also confirmed by the 2017 survey of Deloitte, where solving talent-related issues is the $3^{\text {rd }}$ in the order of importance in the case of the surveyed companies. This is also underlined by the fact that 8 out of 10 managers consider the acquisition of talent very important for future operation, according to the same survey. This managerial opinion can be explained by earlier predictions that HR departments might disappear in the future and they might be replaced by talent development departments (Rothwell, 2008). Consequently, Bersin (2008), one of the excellent representatives of talent management outlined a possible development in HR where progress towards talent management is an inevitable process (Figure 2).

Figure 2: Evolution of the HR Function

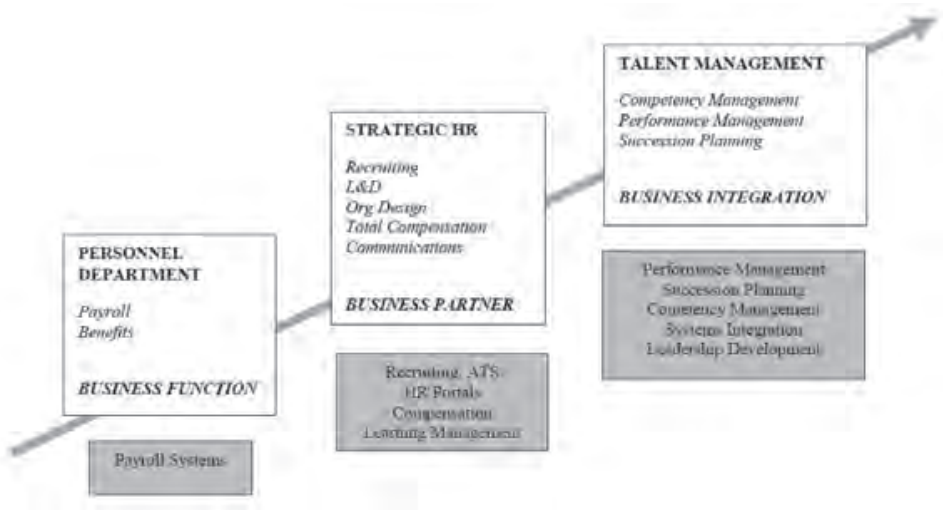

Source: Bersin (2008) 
In order to address the many challenges that organisations face constantly, HR aims to provide a long-term sustainable system of operation in response to new environmental conditions. Among the numerous new challenges, one of the most common problems is the lack of employees, which affects small and large businesses across Europe (Eurostat, 2017). In addition to the general problem of employee shortage, constant aging of society - even in the most advanced western countries results in a situation, where the decreasing number of available workforce is unable to finance social supply systems. In time, this might grow to a state that is threatening to the entire economy and does not affect the functioning of organisations only (Gulyás, 2005a). An alternative way to deal with the situation is the extension of working hours, which is practiced frequently both in Germany and France (Gulyás, 2005b). Csehné (2018) points out that in order to improve the situation, it would be necessary to provide more detailed and comprehensive information towards employees on the current situation of the labour market. Additionally, a more detailed study of some regions of Hungary could contribute to the management of employee shortage situation and consequently to the more direct search of talented employees. Talent management is designed to help organisations - despite the decreasing amount of human capital find the employees who can achieve their business ideas, and reach the segment of employees with talents most relevant to the company. If obtaining talented workers is a precondition of achieving business goals, focus on talent search is of central importance. Managing talents is therefore not only an HR-related issue, but it has grown into a task of strategic significance.

\section{Work should not be emphasised as a compulsory activity in the future, but rather an experience}

The importance of work flow is not a particularly new field of research, but nowadays it is increasingly becoming a popular topic in the perspective of progressive HR. The special character of the topic is that it bears importance both for employees and employers. If we look at one side of the story and examine the viewpoint of the employer, it can be concluded that gaining work flow is important for a number of human resource management functions as highlighted in the previous century. Such functions are selection (Ash-Levine, 1985), trainings (Ford et al., 1992) and career development (Campion et al., 1994; McCall et al., 1988) as well. Observing the other side of the issue, Deloitte has made it clear in the 2017 trends summarising global human capital that in the advanced digital world of our age, it is the general expectation of employees for the job to be attractive, result-oriented and enjoyable. In addition to employee engagement and work culture, an increasingly dominant presence is observable in terms of a tendency where companies seek to develop an integrated system that has an impact on the overall work experience - including workplace, human resource management and management practices that affect the work of employees. Due to the advances in technology, multiple tools are available for HR to turn gaining experience more determinant for the individual, such as - among others - 
the increasingly popular workplace wellness and fitness applications which are linked to an extensive feedback toolset. So what are the options of organisations to intend to open towards the new trend and to focus on the experience gain of their employees at their workplace? It is important to dedicate attention towards the creation of positive flow even before the start of work; multiple companies try to insert different items of flow into the process of job search, which could later have a positive effect on the involved applicants. Then the focus should shift towards the selection process, where an even more significant impression can be made towards the future employees through a personal encounter. However, after application, there are further multiple areas, the emphasis of which might contribute to the strengthening of positive work experience of the employees (Juhász, 2016). Focusing on the following areas as the major aspects of experience gain related to the organisation, additional impact can be achieved (Onishuk, 2018):

- Make sure you are hiring to fill a real need

- Write clear job descriptions

- Make it easy for candidates to apply to your jobs

- Follow-up early and often

- Communicate with (and thank) candidates during each step of the hiring process

- Give candidates information about what to expect at in-person interviews

- Give candidates your full attention at interviews

- Tell candidates if you are no longer considering them, as soon as you can

- If you want to keep certain candidates in mind for future openings, keep track of them

- Be open to giving (and receiving) feedback

Another aspect is the presence of supportive management, including the definition of clear organisational goals, employee support, use of a coach system and an agile performance management system as well. An undeniable component is positive workplace, which includes a flexible and humane working environment, appreciative and welcoming work culture. In addition to this, determination of possibilities for advancement also belongs here; it can be coordinated within the organisation by trainings, talent support, and self-governed learning. Last but not least, confidence towards the organisation which is in many cases defined by the mission and purpose of the organisation can also be a tool, which is further completed by honest and inspiring organisational culture. The above factors, supporting the increasingly dominant labour market and organisational nature of the new trend suggest that focusing on organisational experience gain might become of key importance in terms of maintaining competitiveness and attracting potential employees with modern expectations.

\section{Summary}

Continuity of environmental changes can be interpreted as a fundamental tendency of economic operation. A concomitant of the natural character of change is the proper 
response to it; areas of business life are no exception in this regard. As the most significant factors of environmental change from the point of view of HR - which can be interpreted as challenges as well - lack of employees and changing expectations of employees and employers have an impact that results in the emergence of new functions. At the same time, former traditional functions are transformed and become complemented by aspects that have not been functioning yet. Consequently, in the future organisations are forced to shape their operation taking into account new trends and expectations, if they intend to remain successful over the long term. Elaboration of an impressive employer brand and an attractive organisational image aiming at both the internal and external employer environment become factors of paramount importance. As a new point of view, the core task of corporate operation is - beyond acquisition to retain existing staff and to elaborate and apply the relevant strategies in detail.

Progressive approach to work, according to which corporate operation needs to be formed focusing on individual competencies, rather than linking it to static, formal knowledge, is closely linked to the above. Existing individual knowledge has to be transformed through conscious management into organisational knowledge and frameworks are required for its dissemination, while providing the adequate support for individual development as well. In conformity with integrated operation, the approach of talent management needs to prevail, projecting its effect onto the entire HR system and focusing on building the entire organisation based on excellent individuals. The development of this system is supported by numerous modern tools, among which the acquisition of workplace experience is one of the leading methods. By means of its application, creation of flow-based work has to be the fundamental aspiration of the organisation that can be used to innovatively support brand building, and motivate colleagues towards loyalty, which contributes to their retention.

S) Supported by the ÚNKP-17-3. New National Excellence Program of the Ministry of Human Capacities

\section{References}

Allen, D.G. (2008).Retaining Talent - A Guide to Analyzing and Managing Employee Turnover. SHRM Foundation, Alexandria, USA, 57.p. https://www.shrm.org/hrtoday/trends-and-forecasting/special-reports-and-expert-views/Documents/RetainingTalent.pdf

Ambler, T. - Barrow, S. (1996).The employer brand. Journal of Brand Management, 4 (3), 185-206

Ash, R.A. - Levine, E.L. (1985).Job applicant training and work experience evaluation: An empirical comparison of four methods. Journal of Applied Psychology, 70. 572-576.p. 
Bencsik A. - Juhász T. (2018). Tudásorientált szervezetek értékítélete a bizalom gazdasági hatásairól. In: Budapest Management Review. Vezetéstudomány. XLIX. 2018.01 szám. 30-39.p. Published by Vorvinus Business School Corvinus University of Budapest

Berde, Cs., Dajnoki, K. (2007).A humánerőforrás gazdálkodás jelentősége és tevékenység területei, In: K. Dajnoki - Cs. Berde (ed.): Humánerőforrás gazdálkodás és vezetés, Szaktudás Kiadó Ház Rt., Budapest, pp.7-16.

Bersin, J. (2008).How talent management changes HR http://blog.bersin.com/howtalent-management-changes-hr/ 2018.01.06.

Campion, M.A. - Cheraskin, L. - Stevens, M.J. (1994).Career-related antecedents and outcomes of job rotation. Academy of Management Journal, 37. 1518-1542.

Canton, J. (2013).Global Futures Forecast 2013: The Top Trends That Will Shape the Coming Year, Institute for Global Futures.

Csedő Cs. - Frajna Piller A. - Horváth A. - Kolbe T. - Kovács T. - Poór J. (2016).Szakemberhiány és munkaerőmegtartás a kulcsmunkakörökben 2016. Kutatásizárójelentés, Budapest, 25.p. ISBN: 978-963-269-591-4

Csehné Papp I. (2018).Regional differences in the assessment of the labour market. In: Studies about the perspectives of social sciences 36-44.p. Szent István University, Gödöllő

Dajnoki K. (2014): Helyet mindenkinek! Fogyatékos, illetve megváltozott munkaképességű munkavállalók HR sajátosságainak feltárása az Észak-alföldi Régióban. Közép-Európai Monográfiák No12, Egyesület Közép-Európa Kutatására, Szeged, 2014. 142. p

Deloitte (2017). Rewriting the rules for the digital age. 2017 Deloitte Global Human Capital Trendshttps://www2.deloitte.com/content/dam/Deloitte/us/Documents/humancapital/hc-2017-global-human-capital-trends-us.pdf 2017.09.27.

Eurostat (2017). Europe 2020 indicators-employment. http://ec.europa.eu/eurostat/statistics-explained/index.php/Europe_2020_indicators__employment 2018.01.10.

Felnőttképzési törvény (2001).2001. évi CI. Törvény a felnőttképzésről. V. Rész, 29.§, 10. pont. https://mkogy.jogtar.hu/?page=show\&docid=a0100101.TV

Ferry, K. (2014).Talent management best practice series. Strategic alignment. ISBN:978-0-9885598-7-5

Figurska, I. - Matuska, E. (2013). Employer branding as a human resources management strategy. In Human Resource Management \& Ergonomics, vol. VII./2. 
Ford, J.K. - Quinones, M.A.-Sorra, J. (1992).Factors affecting the opportunity to perform trained task on the job. Personnel Psychology, 45, 511-572.p.

Gergely É. - Madarász T. - Pierog A. (2017).A magasszintű teljesítményhez szükséges háttértényezők feltárása hallgatói mintán, Taylor: Gazdálkodás- és Szervezéstudományi Folyóirat: A Virtuális Intézet Közép-Európa Kutatására Közleményei IX. évf. 1. sz.:(No. 27.) pp. 139-145.

Gray, A. (2016).The 10 skills you need to thrive in the Fourth Industrial Revolutionhttps://www.weforum.org/agenda/2016/01/the-10-skills-you-need-to-thrivein-the-fourth-industrial-revolution/ 2018.01.06.

Gulyás L. (2005a).Folyamatok és tendenciák néhány Európai Uniós ország munkaerőpiacán. 1. rész: A német munkaerőpiac jellemzői 1998-2004. In: Humánpolitikai Szemle 3. szám. 84-96 p.

Gulyás L. (2005b). Folyamatok és tendenciák néhány Európai Uniós ország munkaerőpiacán. 2.rész: A francia munkaerőpiac jellemzői 1998-2004. In: HumánpolitikaiSzemle 4. szám. 89-96 p.

Hegedűs E.- Nagy R. (2017). Nemzetközi munkaadói márkaépítés, BDO Felmérés, (https://www.bdorecruitment.hu/BDO/web.nsf/Pub/NHJ1T7.html In: Kovács K. Az Employer Branding helyzeteMagyarországon. 59th Georgikon Scientific Conference, pp. 282-292.

Hrportal (2017).Milesz a HR kulcsfeladataaz idén?https://www.hrportal.hu/hr/mi-lesza-hr-kulcsfeladata-iden-20170106.html

Hrportal (2018). A megtartáslesz a HR 2018-as kulcsfeladata https://www.hrportal.hu/hr/a-megtartas-lesz-a-hr-2018-as-kulcsfeladata-20180115.html

Huselid, M. A. (1995).The Impact of Human Resource Management Practices on Turnover, Productivity, and Corporate Financial Performance, Academy of Management Journal 38, 635-72.

Juhász Cs. (2016): Elvárások és elégedettség Taylor: Gazdálkodás- és Szervezéstudományi Folyóirat: A Virtuális Intézet Közép-Európa Kutatására Közleményei24:(3) pp.58-64.

Key Competencies. A Developing Concept in General Compulsory Education. The Information Network on Education in Europe. Eurydice, European Unit. Brussels, 2002.

Kim, D. (2012).HR Branding: How Human Resources Can Learn from Product and Service Branding to Improve Attraction, Selection, and Retention. [Electronic article]. Cornell Hospitality Report, 12(14), 6-17.

scholarship.sha.cornell.edu/cgi/viewcontent.cgi?article=1061\&context=chrpubs 
Laakso-Manninen, R - Viitala, R (2007).Competence management and Human resource development. A theoretical framework for understanding the practices of modern Finnish organisations. http://www.haaga-helia.fi/sites/default/files/Kuvat-jaliitteet/Palvelut/Julkaisut/hrdweb.pdf 2018.01.05.

McCall, M.W. - Lombardo, M.M. - Morrison, A.M. (1988). The lessons of experience. New York: Lexington.

McLagan, P.A. (1998)."What is a Competency". Training, June, 58-64.

Minchington, B. (2013).The Rise of Employer Brand Leadership, Second Ed., Oct. 2013. (online) Available on: http://www.employerbrandinginternational.com, pdf.

Mosley, R. (2009). Employer Brand. The Performance Driver No Business Can Ignore. A Shoulders of Giants Publication.

Onishuk, E. (2018).How to impove candidate experience https://resources.workable.com/tutorial/candidate-experience 2018.01.03.

Parry, S.B. (1996.): "The Quest for Competencies". Training, July, 46-56.

Poór J. - Kolbe T. - Kovács I. É. - Sinka R. (2012).Megtartás - Fluktuáció; Magyarországi vállalatok és intézmények megtartási és fluktuációkezelési gyakorlata. Kutatási zárójelentés. Humán Szakemberek Országos Szövetsége, Budapest, 32.p

Rothwell, W.J. (2008).Introducing talent management. A Dale Carnegie White Paper https://www.dalecarnegie.co.uk/knowledge_center/white_papers/download/talent_man agement/ 2018.01.04.

SzabóSz. (2012).Gyakorlatorientált, kompetenciaalapú oktatása HR jövőjének kulcsa. 165-177 p. In: Poór J. - Karoliny M-né - Berde Cs. - Takács S. szerk.: Átalakulóemberierőforrásmenedzsment. CompLexKiadó, Budapest, 534.p.

Taylor, K. (2016).Chick-fil-A is beating every competitor by training workers to say 'please' and 'thank you, Business Insider, October 3, http://www.businessinsider.com/chick-fil-a-is-the-most-polite-chain-2016-10

Thomas, A. (2017).5 Things Successful Companies Do to Retain Top Talenthttp://www.selectinternational.com/blog/bid/148239/5-things-successfulcompanies-do-to-retain-top-talent

VeresnéSomosi M. (2013).Teljesítményalapú szervezetalakítás elmélete és módszertana. Miskolci Egyetem, Gazdaságtudományi Kar. ISBN: 978-963-358-049-3

Wojtaszczyk, K. (2012).Employer branding czyli zarządzanie marką pracodawcy. Łódź: Wydawnictwo Uniwersytetu Łódzkiego. 
Youndt, M. A., Snell, S. A., Dean, J. W. Jr., and Lepak, D. P. (1996).Human Resource Management, Manufacturing Strategy, and Firm Performance, Academy of Management Journal 39, 836-66.

\section{Summary}

Continuity of environmental changes can be interpreted as a fundamental tendency of economic operation. A concomitant of the natural character of change is the proper response to it; areas of business life are no exception in this regard. As the most significant factors of environmental change from the point of view of HR, which can be interpreted as challenges as well, lack of employees and changing expectations of employees and employers have an impact that results in the emergence of new functions. At the same time, former traditional functions are transformed and become complemented by aspects that have not been functioning yet. Consequently, in the future organisations are forced to shape their operation taking into account new trends and expectations, if they intend to remain successful over the long term. Elaboration of an impressive employer brand and an attractive organisational image aiming at both the internal and external employer environment become factors of paramount importance. As a new point of view, the core task of corporate operation is beyond acquisition to retain existing staff and to elaborate and apply the relevant strategies in detail.

Progressive approach to work, according to which corporate operation needs to be formed focusing on individual competencies, rather than linking it to static, formal knowledge, is closely linked to the above. Existing individual knowledge has to be transformed through conscious management into organisational knowledge and frameworks are required for its dissemination, while providing the adequate support for individual development as well. In conformity with integrated operation, the approach of talent management needs to prevail, projecting its effect onto the entire HR system and focusing on building the entire organisation based on excellent individuals. The development of this system is supported by numerous modern tools, among which the acquisition of workplace experience is one of the leading methods. By means of its application, creation of flowbased work has to be the fundamental aspiration of the organisation that can be used to innovatively support brand building, and motivate colleagues towards loyalty, which contributes to their retention. 